\title{
ANALYSIS OF LION AIR'S COMPETITIVE STRATEGY IN BUSINESS COMPETITION FOR SCHEDULED AIR TRANSPORT SERVICES IN INDONESIA
}

\author{
Tiarto ${ }^{1}$ \\ 1. Sekolah Tinggi Penerbangan Indonesia \\ $\square$ corresponding author: tiartomustadja@rocketmail.com.
}

\begin{abstract}
Currently, Lion is in big trouble. The aim of this research is to analyze the application competitive strategy of Low Cost Carrier (LCC) taken by Lion in business competition of scheduled commercial air transport services in Indonesia. Through measurement of market concentration : Concentration Ratio (CR), Index (HHI) and number of equal sellers Lion has won the competition as the largest market share holder since 2007 until now. Its success is because Lion is able to successfully cope with five competitive forces (Porter) : (1) buyer, (2) suppliers, (3) substitution, (4) newcomers, (5) rivalries, with LCC strategy. LCC can last long but not forever. The evolution of the value industry of the LCC strategy of excellence declined, pushing a heavy burden for Lion. Urgent need of strategy or other new business model, with strategic partners (domestic and foreign) to maintain and even improve company performance in the framework of Sustainable Competitive Advantage (SCA).

Keywords: Market Concentration, Low Cost Carrier (LCC), Competition.
\end{abstract}

\section{Introduction}

PT. Lion Mentari Air, hereinafter abbreviated Lion, is the first airline company in Indonesia to declare itself as a Low Cost Carrier (LCC).

Through vision "We Make People Fly" want to give the image to the public that anyone can fly with Lion at affordable (www. Lionair,co.id).

Lion's initial business capital has only 1 (one) aircraft, approximately seven years later since 1999 has been able to dominate the aviation business in Indonesia. (Peter F. Drucker n.d.) defines business as an organization that adds value and creates wealth. Therefore, on November 18, 2011 President Director of Lion, Rusdi Kirana has signed a purchase contract of 230 units of B737 aircraft worth US.\$21.7 billion or equivalent to 195 trillion rupiah. Then in March 2013 also signed another contract purchase of 234 Airbus aircraft worth US.\$24 billion or 230.4 trillion rupiah. It is planned that by 2027 the number of Lion's fleets will reach 770 aircraft (Indonesiareview.com) 
The results of the study (Indra S. et. Al., 2015) in the Journal of Transportation and Logistics Management (JMTRANSLOG) STMT Trisakti, concluded that airlines deregulation led to the emergence of low-cost new airlines. Previously by (Kuntjoroadi, Wibowo, Safitri, Nurul;, 2009) in Journal of Business \& Bureaucracy University of Indonesia, stated that based on analysis of BCG matrix (Boston Consulting Group), Garuda's competitive position was in the "star" position until 2007, which means that Garuda has a relative high market share in the growth of the airlines industry market in Indonesia.

However, based on table 1 , if the previous aviation business was always dominated by Garuda, actually since 2007 until now Lion managed to dominate the national airlines business.

Table 1. Market Share (MS) of Domestic Air Transport Passengers Based on the National Air Transport Agency Year 2012-2016 (tens of thousands)

\begin{tabular}{|c|c|c|c|c|c|c|c|c|c|c|c|}
\hline \multirow[t]{2}{*}{ No } & \multirow[t]{2}{*}{ Airline } & \multicolumn{10}{|c|}{ Year 2012-2016 } \\
\hline & & $\begin{array}{c}201 \\
2\end{array}$ & MS & $\begin{array}{c}201 \\
3\end{array}$ & MS & 2014 & MS & $\begin{array}{c}201 \\
5\end{array}$ & MS & $\begin{array}{c}201 \\
6\end{array}$ & MS \\
\hline 1. & PT. Batavia & 697 & $\begin{array}{r}9,8 \\
\%\end{array}$ & - & - & - & & - & - & - & - \\
\hline 2 & $\begin{array}{l}\text { PT. } \\
\text { Mandala }\end{array}$ & 13 & $\begin{array}{r}0,1 \\
\%\end{array}$ & 80 & $1 \%$ & 15 & $0,2 \%$ & - & $0 \%$ & - & - \\
\hline 3. & $\begin{array}{l}\text { PT. } \\
\text { Garuda }\end{array}$ & $\begin{array}{r}153 \\
0 \\
\end{array}$ & $21 \%$ & $\begin{array}{r}167 \\
3 \\
\end{array}$ & $22 \%$ & 1829 & $24 \%$ & $\begin{array}{r}199 \\
7\end{array}$ & $26 \%$ & $\begin{array}{r}199 \\
7\end{array}$ & $22 \%$ \\
\hline 4. & $\begin{array}{l}\text { PT. } \\
\text { Merpati }\end{array}$ & 252 & $\begin{array}{r}3,5 \\
\% \\
\end{array}$ & 136 & $\begin{array}{r}1,8 \\
\%\end{array}$ & - & - & - & - & - & $0 \%$ \\
\hline 5. & PT. I. A. A. & 217 & $\begin{array}{r}3.0 \\
\%\end{array}$ & 302 & $\begin{array}{r}3,9 \\
\%\end{array}$ & 311 & $4 \%$ & 207 & $2 \%$ & 133 & $1,5 \%$ \\
\hline 6. & PT. Pelita & 0,6 & $\begin{array}{r}0,0 \\
\%\end{array}$ & 1 & $\begin{array}{r}0,0 \\
\%\end{array}$ & 0,1 & $0 \%$ & - & $0 \%$ & - & $0 \%$ \\
\hline 7. & PT. Lion & $\begin{array}{r}294 \\
4\end{array}$ & $41 \%$ & $\begin{array}{r}326 \\
1\end{array}$ & $43 \%$ & 3113 & $41 \%$ & $\begin{array}{r}264 \\
9\end{array}$ & $35 \%$ & $\begin{array}{r}309 \\
3\end{array}$ & $35 \%$ \\
\hline 8. & $\begin{array}{l}\text { PT. } \\
\text { Sriwijaya }\end{array}$ & 810 & $11 \%$ & 867 & $11 \%$ & 784 & $10 \%$ & 714 & $9 \%$ & 840 & $9,4 \%$ \\
\hline 9 & $\begin{array}{l}\text { PT. Travel } \\
\text { E. }\end{array}$ & 34 & $\begin{array}{r}0,5 \\
\% \\
\end{array}$ & 68 & $\begin{array}{r}0,8 \\
\% \\
\end{array}$ & 61 & $0,8 \%$ & 41 & $0,5 \%$ & 46 & $0,5 \%$ \\
\hline 10 & $\begin{array}{l}\text { PT. Wings } \\
\text { A. }\end{array}$ & 259 & $\begin{array}{r}3,6 \\
\% \\
\end{array}$ & 342 & $\begin{array}{r}4,5 \\
\% \\
\end{array}$ & 343 & $4 \%$ & 343 & $4,5 \%$ & 490 & $5,5 \%$ \\
\hline 11 & $\begin{array}{l}\text { PT. } \\
\text { Trigana } \\
\end{array}$ & 1 & $\begin{array}{r}1,3 \\
\% \\
\end{array}$ & 80 & $1 \%$ & 68 & $0 \%$ & 51 & $0,6 \%$ & 50 & $0,5 \%$ \\
\hline 12 & PT. I. A.T. & 2 & $\begin{array}{r}0,0 \\
\% \\
\end{array}$ & 6 & $0 \%$ & - & - & - & - & - & - \\
\hline & & & & & & & & & & & \\
\hline
\end{tabular}


Table 1, Cont. Market Share (MS) of Domestic Air Transport Passengers Based on the National Air Transport Agency Year 2012-2016 (tens of thousands)

\begin{tabular}{|c|c|c|c|c|c|c|c|c|c|c|c|}
\hline 13 & PT. Kalstar & 55 & $\begin{array}{r}0,7 \\
\%\end{array}$ & 62 & $\begin{array}{r}0,8 \\
\%\end{array}$ & 98 & $1,3 \%$ & 87 & $1,1 \%$ & 85 & $0,9 \%$ \\
\hline 14 & $\begin{array}{l}\text { PT. Travira } \\
\text { Air }\end{array}$ & 0,2 & $0 \%$ & 0 & $0 \%$ & 0,1 & $0 \%$ & - & $0 \%$ & - & $0 \%$ \\
\hline 15 & $\begin{array}{l}\text { PT. } \\
\text { Aviastar } \\
\text { M. }\end{array}$ & 18 & $\begin{array}{r}0,2 \\
\%\end{array}$ & 18 & $\begin{array}{r}0,2 \\
\%\end{array}$ & 18 & $0,2 \%$ & 8 & $0,1 \%$ & - & $0 \%$ \\
\hline 16 & $\begin{array}{l}\text { PT. } \\
\text { Trasnusa }\end{array}$ & 20 & $\begin{array}{r}0,3 \\
\%\end{array}$ & 19 & $\begin{array}{r}0,2 \\
\%\end{array}$ & 23 & $0,3 \%$ & 19 & $0,2 \%$ & 7 & $0 \%$ \\
\hline 17 & PT.ASI P. & 28 & $\begin{array}{r}0,4 \\
\%\end{array}$ & 22 & $\begin{array}{r}0,2 \\
\%\end{array}$ & 8 & $0,1 \%$ & 4 & $0 \%$ & 3 & $0 \%$ \\
\hline 18 & PT. Sky A. & 23 & $\begin{array}{r}0,3 \\
\% \\
\end{array}$ & 35 & $\begin{array}{r}0,4 \\
\% \\
\end{array}$ & 2 & $0 \%$ & - & $0 \%$ & - & - \\
\hline 19 & PT. Pacific & 1 & $\begin{array}{r}0,0 \\
\%\end{array}$ & - & - & - & - & - & - & - & \\
\hline 20 & PT. Citilink & 144 & $2 \%$ & 535 & $7 \%$ & 755 & $10 \%$ & 937 & $12 \%$ & $\begin{array}{r}110 \\
5\end{array}$ & $12 \%$ \\
\hline 21 & $\begin{array}{l}\text { PT. Batik } \\
\text { Air. }\end{array}$ & - & $0 \%$ & 77 & $3 \%$ & 188 & $2,5 \%$ & 460 & $6 \%$ & 739 & $8,3 \%$ \\
\hline 22 & $\begin{array}{l}\text { PT. Nam } \\
\text { Air. }\end{array}$ & - & & - & - & 35 & $0,4 \%$ & 121 & $1,5 \%$ & 242 & $2,7 \%$ \\
\hline 23 & $\begin{array}{l}\text { PT. I. } \\
\text { A.A.Exstra }\end{array}$ & - & & - & - & - & $0 \%$ & 26 & $0,3 \%$ & 96 & $1 \%$ \\
\hline 1. & Total & $\begin{array}{r}714 \\
2 \\
\end{array}$ & $\begin{array}{c}100 \\
\%\end{array}$ & $\begin{array}{r}757 \\
7 \\
\end{array}$ & $\begin{array}{r}100 \\
\% \\
\end{array}$ & $\begin{array}{r}7649 \\
8\end{array}$ & $\begin{array}{r}100 \\
\%\end{array}$ & $\begin{array}{r}766 \\
3\end{array}$ & $\begin{array}{r}100 \\
\%\end{array}$ & $\begin{array}{r}892 \\
7\end{array}$ & $\begin{array}{r}100 \\
\%\end{array}$ \\
\hline 2. & Growth & & $19 \%$ & & $6 \%$ & & $0,9 \%$ & & $0,2 \%$ & & $17 \%$ \\
\hline
\end{tabular}

Explanation : MS (Market Share).

PT. Batavia Air stops operation in 2013.

PT. Batik Air started operation in January 2013

$>$ PT. Citilink Indonesia starts operation in August 2012

PT. I.A.T (Indonesia Air Transport) stop operation in 2013

PT. Mandala Airlines stops operation in July 2014

$>$ PT. Merpati Nusantara Airlines stops in February 2014

PT. Nam Air starts operation in December 2013

Source : Directorate General of Air Communication, 2017

According to Head of PPM Consulting Division (Aruan K. (2015), there are only two prevailing general options : an extra service or a price competition (LCC) strategy. Garuda prefer to use extra service strategy, while Lion tend to 
price competition strategy LCC. LCC or no frills is a competitive strategy of overall cost advantage that is more specific to the aviation business. The tendency of passengers to choose LCC flights encourages more airlines to compete to offer LCC. As a result, they are worried about loosing customer if they continue to run only one strategy. When the strategy changed, Lion holding LCC flights as well as full service flights, and vice versa, Garuda instead of full service flights also penetrated the LCC flight. They are also forming strategic alliances with their partners. Garuda with its subsidiary Citilink, the same thing is also known by Lion with his subsidiary Batik Air. If Citilink is set up to compete against the Lion in its low-cost competition strategy (LCC), Batik Air to compete against Garuda in terms of premium price (full service). The same thing was done by Sriwijaya Air with its subsidiary Nam Air, as well as Indonesia Air Asia with Indonesia Air Asia Extra.

Now almost all airlines run the same strategy. The reason for the flexibility of organization is as if the division of tasks or roles - Lion for LCC air travelers, while Batik Air has a role in running a full service strategy. Therefore, Lion, Garuda, Sriwijaya and other airlines doing the same thing did not present anything. As (Magretta, 2012) : "When you change strategy with flexibility, your organization will never represent anything or be good in anything". This is because the airlines in question at the same time serve the same customers and meet the same needs and sell the price with the same relative price. This means Lion has not had a strategy, because the Lion is now run the same as other airlines.

In addition, the LCC's superiority exerts a heavy burden on Lion to maintain its position, which means reinvestment of capital for modern equipment, the unquestionable disposal of the wealth of old aircraft that has been worn. Therefore in 2011 and 2013 Lion has ordered 464 aircraft from Boeing and Airbus. Now the aircraft began to arrive and it was difficult for delivery to be postponed. To make money, the planes must fly. To be able to fly there must be 
a permit to fly. Flight approval covers the need for hard and soft infrastructures. Hard infrastructure on domestic flights is the problem of airport density, the depletion of aircraft parking at airports in Indonesia. While the infrastructure is primarily the right to fly (traffic right). The number of passengers transported has risen more than 10 times than before the deregulation, but since the economic crisis there is no new airport development (beritatransnews.co.id, 2015). This means Lion must focus on foreign flights, but this too many obstacles. In order to utilize the aircraft and the development of market share Lion is trying to establish cooperation with foreign partners : Malaysia, Thailand, Sri Lanka, Vietnam, Australia and so on but only interested Malindo Airways from Malaysia (Gerryonline.blogspot.co.id, 2015). The many problems make great difficulty for Lion (Rosyid 1999).

\section{Method}

This research uses approach of conception of building/constructivism approach (Haula R, 2011). This is an industrial economic policy study focused on the use of five industrial structural strength evaluations by Porter (2008). Data were extracted and obtained through literature studies, in-depth interviews and intense discussions with practitioners in the field of aviation. Data and information obtained from several institutions. In the instant the government is conducted at the Directorate of Air Transportation, Directorate General of Civil Aviation, at non government institutions such as INACA (Indonesian National Air Carrier Association) and KPPU (Business Competition Supervisory Commission). As key informant General Director of Air Transportation. The analyzed policies cover several aspects in the field of air transport operations in Indonesia contained in : Flight Laws No. 15/1992 and its successor no. : 1/2009). While in the aviation industry focused on airlines Lion and Garuda.

The results and discussion are based on the main elements of the market structure. In measuring the market concentration, two tools are used: 1) The 
concentration ratio $(\mathrm{CR})$, ie calculating the percent of output dominated by dominant firms (R. Pratama and M. Manurung, 2002), and 2). HerfindahlHirschman Index is abbreviated as HHI. HHI is calculated by squaring the percentage of the market share of each airline and then summing it up. If an industry consists of 100 companies of the same size, then the HHI is $=100 \times(1)^{2}$. If the industry is a pure monopoly, its index is $10,000=(100)^{2}$. HHI formula (William McEachern, 2000). Calculation results of Ratio Concentration/CR, HHI and number of competing companies as table 2 below.

Table 2.

Market Concentration : (Consentration/CR and Herfindahl-Hiersman Index/HHI)

Market Share Domestic Scheduled Commercial Air Transpot Service (2007-2016)

Category : Passengger Carried.

\begin{tabular}{|c|c|c|c|c|c|c|c|c|c|c|c|}
\hline \multirow[t]{2}{*}{ No } & \multirow[t]{2}{*}{ Airline } & \multicolumn{10}{|c|}{ Year 2007-2016 } \\
\hline & & 2007 & 2008 & 2009 & 2010 & 2011 & 2012 & 2013 & 2014 & 2015 & 2016 \\
\hline 1. & $\begin{array}{l}\text { PT. } \\
\text { Batavia } \\
\text { Air }\end{array}$ & 171 & 163 & 194 & 171 & 126 & 95 & 1 & 0,4 & - & - \\
\hline 2 & $\begin{array}{l}\text { PT. } \\
\text { Mandala } \\
\text { Airlines }\end{array}$ & 20 & 85 & 66 & 21 & - & - & - & - & - & - \\
\hline 3. & $\begin{array}{l}\text { PT. } \\
\text { Garuda } \\
\text { Indonsia }\end{array}$ & 637 & 420 & 367 & 372 & 518 & 459 & 488 & 572 & 677 & 500 \\
\hline 4. & $\begin{array}{l}\text { PT. } \\
\text { Merpati }\end{array}$ & 46 & 44 & 26 & 12 & 13 & 14 & 3 & - & - & - \\
\hline 5. & $\begin{array}{l}\text { PT. } \\
\text { Indonesia. } \\
\text { A. A. }\end{array}$ & 20 & 16 & 11 & 4 & 5 & 12 & 20 & 16 & 7 & 2 \\
\hline 6. & $\begin{array}{l}\text { PT. Pelita } \\
\text { Air Servic }\end{array}$ & 0 & 0 & 0 & 0 & 0 & 9 & 0 & 0 & 0 & - \\
\hline 7. & $\begin{array}{l}\text { PT. Lion } \\
\text { Air }\end{array}$ & 816 & 607 & 933 & 1448 & 1721 & 1699 & 1852 & 1656 & 1195 & 1200 \\
\hline
\end{tabular}

Source : Tiarto, 2017 (data prosseced). 
Table 2, Cont.

\begin{tabular}{|c|c|c|c|c|c|c|c|c|c|c|c|}
\hline 8. & $\begin{array}{l}\text { PT. } \\
\text { Sriwijaya }\end{array}$ & 83 & 130 & 156 & 184 & 138 & 129 & 129 & 105 & 87 & 89 \\
\hline 9 & $\begin{array}{l}\text { PT. } \\
\text { Travel } \\
\text { Expres } \\
\text { A. }\end{array}$ & 0,4 & 0,5 & 0,5 & 0,3 & 0,2 & 0,2 & 0,7 & 0,6 & 0,3 & 0,3 \\
\hline 10 & $\begin{array}{l}\text { PT. } \\
\text { Wings } \\
\text { Abadi A. }\end{array}$ & 30 & 39 & 8 & 2,6 & 11 & 13 & 20 & 20 & 20 & 30 \\
\hline 11 & $\begin{array}{l}\text { PT. } \\
\text { Trigana } \\
\text { A.S. }\end{array}$ & 3,5 & 3,5 & 1,3 & 1,2 & 1,5 & 1,6 & 1,1 & 0,8 & 0,4 & 0,3 \\
\hline 12 & $\begin{array}{l}\text { PT. I. } \\
\text { A.T. }\end{array}$ & 0 & 0 & 0,1 & 0 & 0 & 0 & 0 & - & - & - \\
\hline 13 & $\begin{array}{l}\text { PT. } \\
\text { Kalstar } \\
\text { Aviation }\end{array}$ & - & 0 & 0,8 & 0,3 & 0,9 & 0,1 & 0,7 & 1,6 & 1,3 & 0,9 \\
\hline 14 & $\begin{array}{l}\text { PT. } \\
\text { Travira } \\
\text { Air }\end{array}$ & & - & - & 0,2 & 0 & 0 & 0 & 0 & - & - \\
\hline 15 & $\begin{array}{l}\text { PT. } \\
\text { Aviastar } \\
\text { M. }\end{array}$ & & & - & 0 & 0,1 & 0 & 0 & 0 & 0 & - \\
\hline 16 & $\begin{array}{l}\text { PT. } \\
\text { Trasnusa } \\
\text { A.M. }\end{array}$ & & & & & 0 & 0 & 0 & 0 & 0 & 0 \\
\hline 17 & $\begin{array}{l}\text { PT.ASI } \\
\text { Pujiastuti }\end{array}$ & & & & & - & 0,1 & 0,1 & 0 & 0 & 0 \\
\hline 18 & $\begin{array}{l}\text { PT. Sky } \\
\text { Aviation. }\end{array}$ & & & & & - & 0,1 & 0,2 & 0,1 & 0 & - \\
\hline
\end{tabular}


Table 2, Cont.

\begin{tabular}{|c|c|c|c|c|c|c|c|c|c|c|c|}
\hline 19 & $\begin{array}{l}\text { PT. } \\
\text { Pacific } \\
\text { Royale }\end{array}$ & & & & & - & 0 & - & - & - & - \\
\hline 20 & $\begin{array}{l}\text { PT. } \\
\text { Citilink } \\
\text { Ind. }\end{array}$ & & & & & - & 4,1 & 50 & 97 & 150 & 153 \\
\hline 21 & $\begin{array}{l}\text { PT. Batik } \\
\text { Air. }\end{array}$ & & & & & & 0 & 1 & 6 & 36 & 65 \\
\hline 22 & $\begin{array}{l}\text { PT. Nam } \\
\text { Air. }\end{array}$ & & & & & & - & - & 0,2 & 2,5 & 7,4 \\
\hline 23 & $\begin{array}{l}\text { PT. } \\
\text { Indonesi } \\
\text { a A.A.E }\end{array}$ & & & & & & & - & 0 & 0,1 & 1,2 \\
\hline $\mathrm{A}$ & $\mathrm{HHI}$ & $\begin{array}{r}182 \\
7\end{array}$ & 1508 & 1764 & 2217 & 2535 & 2436 & 2567 & 2476 & 2177 & 2049 \\
\hline & CR4 & $\begin{array}{r}0,9 \\
34\end{array}$ & $\begin{array}{r}0,87 \\
5\end{array}$ & $\begin{array}{r}0,93 \\
5\end{array}$ & $\begin{array}{r}0,97 \\
8\end{array}$ & $\begin{array}{r}0,98 \\
7\end{array}$ & $\begin{array}{r}0,97 \\
7\end{array}$ & $\begin{array}{r}0,98 \\
1\end{array}$ & $\begin{array}{r}0,98 \\
1\end{array}$ & $\begin{array}{r}0,96 \\
8\end{array}$ & $\begin{array}{r}0,94 \\
7\end{array}$ \\
\hline B & $\begin{array}{l}\text { Number } \\
\text { of equal } \\
\text { seller }\end{array}$ & 5 & 7 & 6 & 5 & 4 & 4 & 4 & 4 & 5 & 5 \\
\hline $\mathrm{C}$ & $\begin{array}{l}\text { CR Lion } \\
\text { to HHI }\end{array}$ & $\begin{array}{r}44, \\
6\end{array}$ & 40,2 & 52,9 & 65,3 & 67,9 & 69,7 & 72,1 & 66,9 & 54,9 & 58,6 \\
\hline
\end{tabular}

According to Porter (2008), there are five competitive forces namely (1) buyer, (2) suppliers (3) replacements/substitution, (4) newcomers and (5) rivalries. The collective strength of the five forces determines the industry's average profitability through its impact on prices, costs, and investment in purchasing new aircraft needed to compete. A good strategy generates better returns than other airlines in general. For any organization that tries to review or formulate a strategy, a 5 (five) strength framework is the place to start, as (Porter 2008) illustrates in chart 1 . 
Chart I.

Industrial Structure: Five Strengths

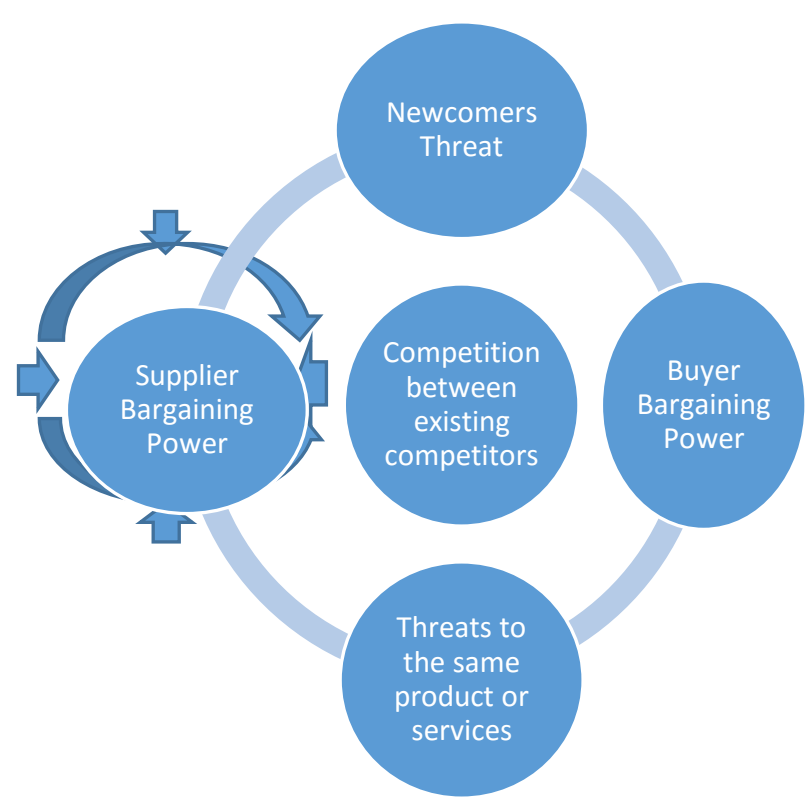

Source : Michael E. Porter, 2008 By Harvard Business Publishing.

\section{Results}

Based on the analysis of market struktur (number and size of buyer distributions (Table 1), Lion's market share since 2007 is always the largest in the aviation business market part of Indonesia. The number of passengers transported during the last five years from 2012 to $2016,41.2 \%, 43 \%, 41 \%, 35 \%, 35 \%$ respectively, while Garuda's second largest rival was $21 \%, 22 \%, 24 \%, 26 \%$ and $22.4 \%$. Previous research, from since the flight in Indonesia until 2005 the biggest market share is always dominated by Garuda state-owned incumbent airlines, 2006 Garuda and Lion market share equals $20 \%$ each. Not surprising if market share Lion is great, because the number of fleets is owned by most other airlines (Erwansyah S. 2017).. This opinion is true when the number of fleets as the only measure of success. However, considering the Lion's growth achievement which at the beginning operation in 1999/2000 had only one aircraft with a market share of $0.6 \%$ (Mufti A, 2007). Only seven years later can match the dominant position 
of Garuda to $20 \%$, and since 2007 as the largest market share holder, it seems difficult to argue that Lion does have superior performance. As Magretta J. (2012) points out: "competitive advantage is not how to beat rivals, it's about creating superior value. Business competition is about struggle for profit”. Lion excelled not only in terms of the size of the market he achieved but also excelled in the value chain created in-between the LCC's business strategy. Based on the analysis of market concentration (Ratio Concentration/CR, HHI Index, and number competing companies are as follow (table 2).CR4 is the concentration ratio in the 4 (four) largest companies. CR4 always shows high above 0,90 (90\%), meaning that the market is concentrated in the 4 (four) large airlines. It also shows that the national aviation industry belongs to the oligopoly market category, since few companies are in the market. Likewise HHI shows average above $>1800$, meaning that the market is classified with high concentration.

Next column B table 2, is the number of companies that can can compete. This figure is obtained from 1 divided by HHI. For example in 2016 amounted to 4,8 (rounded 5), meaning the number of airlines that can compete as many as 5 airlines. From the data above shows that airlines that can compete show decrease, meaning that can compete to be a little, because it is concentrated on the dominant players, 
Table 3

Comparison of Market Share between State-Owned Enterprises (SOEs) and Privately Owned Enterprises (POEs) (Period Before and After Airline Deregulation 1997-2016).

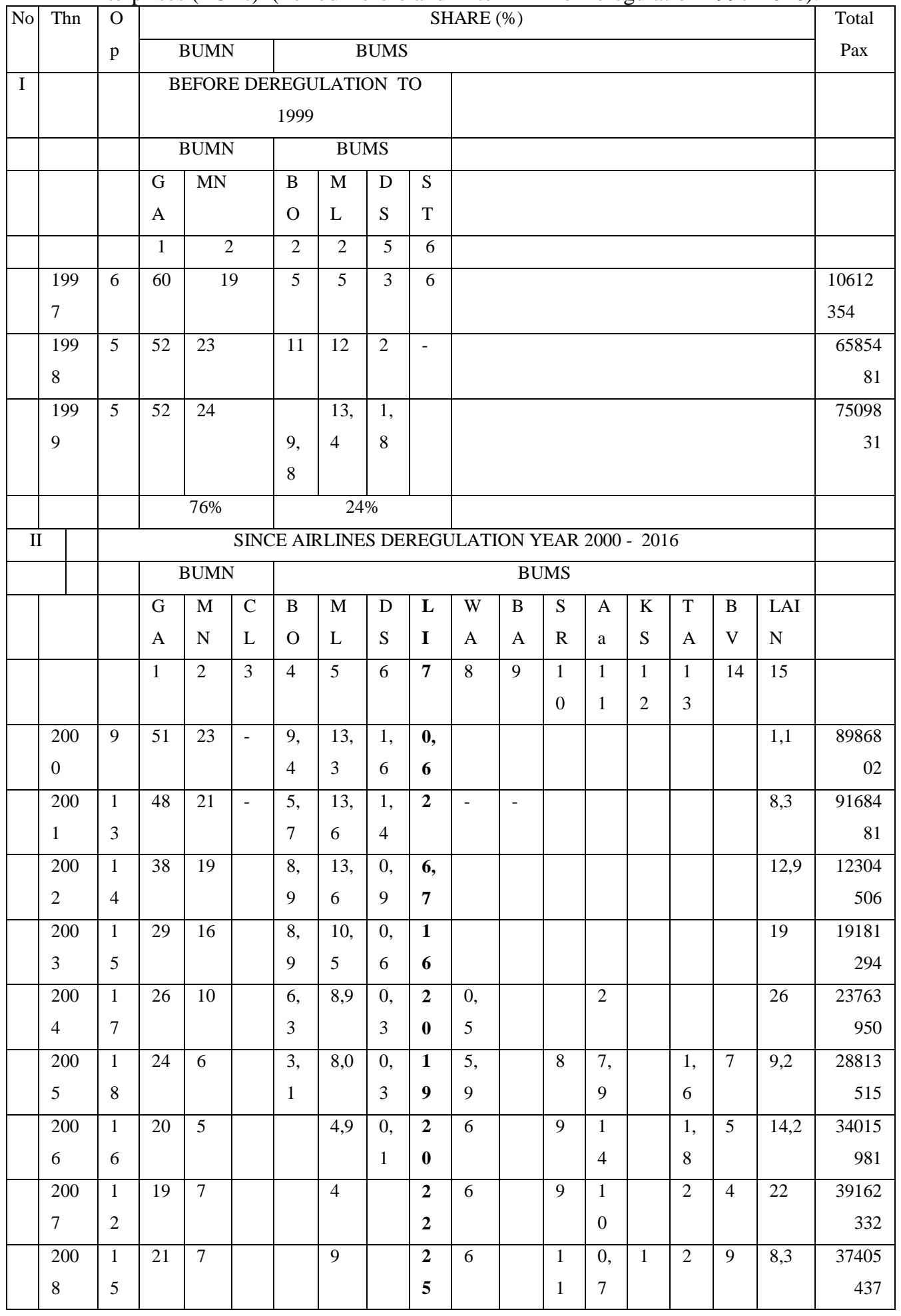


Table 3, Cont.

\begin{tabular}{|c|c|c|c|c|c|c|c|c|c|c|c|c|c|c|c|c|c|}
\hline $\begin{array}{l}200 \\
9\end{array}$ & 1 & 1 & 5 & & & 8 & & $\begin{array}{l}3 \\
1\end{array}$ & 3 & & 14 & & 1 & 1 & 8 & 10 & $\begin{array}{r}4380803 \\
3\end{array}$ \\
\hline $\begin{array}{l}201 \\
0\end{array}$ & 1 & 9 & 4 , & & & 4, & & $\begin{array}{l}3 \\
8\end{array}$ & 2 & & 14 & & $\begin{array}{l}0, \\
6\end{array}$ & 1 & 5 & $\begin{array}{l}11, \\
4\end{array}$ & $\begin{array}{r}5177565 \\
6\end{array}$ \\
\hline $\begin{array}{l}201 \\
1\end{array}$ & 1 & $\begin{array}{l}2 \\
3\end{array}$ & 4 & & & - & & $\begin{array}{l}4 \\
2\end{array}$ & $\begin{array}{l}3, \\
3\end{array}$ & & 12 & & 1 & $\begin{array}{l}1, \\
2\end{array}$ & $\begin{array}{l}1 \\
1\end{array}$ & 2,5 & $\begin{array}{r}6019730 \\
6\end{array}$ \\
\hline $\begin{array}{l}201 \\
2\end{array}$ & 2 & $\begin{array}{l}2 \\
1\end{array}$ & 4 & 2 & & 0 , & & $\begin{array}{l}4 \\
2\end{array}$ & $\begin{array}{l}3, \\
6\end{array}$ & & 11 & & $\begin{array}{l}0, \\
8\end{array}$ & $\begin{array}{l}1, \\
3\end{array}$ & $\begin{array}{l}1 \\
0\end{array}$ & 4,1 & $\begin{array}{r}7142146 \\
4\end{array}$ \\
\hline $\begin{array}{l}201 \\
3\end{array}$ & 1 & $\begin{array}{l}2 \\
2\end{array}$ & 2 & 7 & - & 1 & & $\begin{array}{l}4 \\
3\end{array}$ & $\begin{array}{l}4, \\
5\end{array}$ & 1 & $\begin{array}{l}11, \\
3\end{array}$ & 0 & $\begin{array}{l}0, \\
8\end{array}$ & 1 & - & 6,4 & $\begin{array}{r}7577022 \\
2\end{array}$ \\
\hline $\begin{array}{l}201 \\
4\end{array}$ & 1 & $\begin{array}{l}2 \\
4\end{array}$ & - & 10 & & - & & $\begin{array}{l}4 \\
1\end{array}$ & $\begin{array}{l}4, \\
5\end{array}$ & $\begin{array}{l}2, \\
5\end{array}$ & $\begin{array}{l}10, \\
2\end{array}$ & 4 & $\begin{array}{l}1, \\
2\end{array}$ & 1 & - & 1,6 & $\begin{array}{r}7649840 \\
0\end{array}$ \\
\hline $\begin{array}{l}201 \\
5\end{array}$ & 1 & $\begin{array}{l}2 \\
6\end{array}$ & - & $\begin{array}{l}12, \\
2\end{array}$ & - & - & - & $\begin{array}{l}3 \\
5\end{array}$ & $\begin{array}{l}0, \\
6\end{array}$ & 6 & 9,3 & $\begin{array}{l}2, \\
7\end{array}$ & 1 & $\begin{array}{l}0, \\
6\end{array}$ & - & 8,6 & $\begin{array}{r}7662886 \\
7\end{array}$ \\
\hline $\begin{array}{l}201 \\
6\end{array}$ & 1 & 3 & - & $\begin{array}{l}12, \\
4\end{array}$ & - & - & - & $\begin{array}{l}3 \\
5\end{array}$ & $\begin{array}{l}5, \\
5\end{array}$ & $\begin{array}{l}8, \\
3\end{array}$ & 9,4 & $\begin{array}{l}1, \\
5\end{array}$ & 1 & $\begin{array}{l}0, \\
5\end{array}$ & - & 3,4 & $\begin{array}{r}8927370 \\
1\end{array}$ \\
\hline $\begin{array}{l}201 \\
6\end{array}$ & & \multicolumn{6}{|c|}{$35,4 \%$} & \multicolumn{3}{|c|}{$48,8 \%$} & \multicolumn{6}{|c|}{$15,8 \%$} & \\
\hline $\begin{array}{l}201 \\
6\end{array}$ & & \multicolumn{6}{|c|}{$35,4 \%$} & \multicolumn{9}{|c|}{$64,6 \%$} & \\
\hline
\end{tabular}

Explanation: $\mathrm{Op}=$ Operator/Airlines.

1, $\mathrm{GA}=$ Garuda, 2. $\mathrm{MN}=$ Merpati, 3. $\mathrm{CL}=$ Citilink, $4 . \mathrm{BO}=$ Bouraq. 5.ML = Mandala, 6.DS = Dirgantara Air Service, 6. ST = Sempati, 7. LI = Lion Air, 8.WA = Wing Abadi, 9. $\mathrm{BA}=$ Batik Air, 10.SR = Sriwidjaya, 11.Aa $=$ Adam Air, 12.KS $=$ Kalstar, 13.TA = Trigana Air, 14.BV = Batavia Air, 15.Land $=$ Other.

Source: Tiarto 2007 and 2017 (data processed).

Based on a comparison analysis of market share between State-Owned Entreprices, (SOEs) and Private-Owned Entreprices (POEs) airlines differentiated between before and after airlines deregulation (table 2). Comparison of market share acquisition reflects the result of competition between airlines incumbent and airline entrance. Especially between the Lion group as the entrance with theist Garuda group as incumbent, there has been a reverse development of increased share entrance and decreased incumbent share. if before the deregulation between State-Owned Entreprices (SOEs) with Private-Owner Entreprices (POEs) equal 76\% : 24\%. Whereas after deregulation, 
its growth reversed. For example for 2016 to be $35.4 \%$ : 64.6\% (table 2). The largest growth was dominated by Lion group airline which reached $48.8 \%$ of the total market share of aviation business in Indonesia.

\section{Result and Discussion}

The results show Lion's biggest market share since 2007 until now. This shows that Lion's competitive strategy is superior to competitors. According to the author's description analysis, it is influenced by price competition strategy (LCC). As a newcomer to overcome barriers to entry cheaper than competitors. Lion approaches: (1) reducing product costs, always trying to find ways to produce products at lower cost than competitors. (2) entering the market by selecting fat routes at an affordable price. Sacrificing short-term profits to compel competitors to market for airlines Garuda, Merpati, Bouraq, Mandala etc.

Lion undertakes strategic alliances with partners (domestic and overseas) and in particular with Wing Abadi and Batik Air not only in efforts to develop market markets, as well as in order to avoid allegations of monopolistic practices and unfair business competition. This is because the Lion competing position has been in the approximate market share (50\% and/or 75\%) as meant in Article 27 paragraphs 1 and 2 of Law No. 5 of 1999.

Lion started his business with Michael E. Porter (2008) approach with 5 (five) competitive forces. To cope successfully with the five competitive forces and thereby get a high return on investment for the company, the strategy or business model Lion runs as follows. :

1) Newcomers (threat of newcomers). At the beginning of deregulation the terms of setting up a scheduled airline is very easy, enough to master two aircraft ( 1 owned and 1 leased base on KM11/2001), from the previous 5 to 73 airlines listed. So newcomers are always there and become a permanent threat. Lion's luck was also attributed to the September 11 tragedy of 2001, earning a very cheap airfare. 
2) Purchaser (buyer bargaining power), Since the beginning of the operation Lion build motto "we make people fly" as a supporter of the LCC strategy. Through this vision it gives an image to the consumer that anyone can fly with Lion. Even poor people who are poor even dream of flying with Lion through the lottery advertised on television. Inexpensive imagery has imprinted on the psyche of consumers, even though the price of their purchased tickets is not necessarily cheap. This means that Lion's value proposition is unique, considered a god helper for consumers who want to use airlines at low prices, making air travel consumers switch to the Lion. Not only from fellow competitors of air transport services, but also from other modes of transportation, land and sea.

3) Supplier (Supplier Bargaining Power). The union labour particular in aviation, in particular, have a high bargaining power. They demanded a very high salary because of the difficulty and scarcity of getting a pilot in Indonesia at that time. The pilot salary in Indonesia can be 20-25 times compared to ordinary administrative personnel with the same qualifications. Lion, however, preferred the human resources of retired Air Force aviators, contracted under a cheaper salary standard. The two take advantage of the exertion of foreign aviators. Foreign pilots can sometimes be cheaper, especially from a socialist country (Russia, Czechoslovakia, etc.), through an after sales services engagement. Foreign pilots and mechanics are willing to be paid cheaply to simply turn on their License. The bargaining power of suppliers from aircraft makers / tenants also has great strength. Lion still has a better strategy than a competitor. For example, if at the beginning of deregulation Lion would prefer an old aircraft rental with lessor for the type of aircraft that is generally no longer used in Europe and America but still feasible operated in Indonesia so that it can get a very cheap aircraft rental to be able to set rates lower than competitors. While in the next period Lion 
prefer to order new aircraft as much as possible to get a larger discount, as well as a promotion.

4) Substitutes (Threats of replacement products or services). Garuda, Merpati and other incumbent airlines generally use standard industry rates (food, beverage, first class, business class, economy class etc.) so that the price becomes very expensive for price sensitive consumers. Instead Lion does not recognize standard industry tariffs. Takes advantage of the flight facilities (airport, groundhandling etc.) that are really needed to save operational costs. Selling service at varying prices, flying by the same plane but the price of each seat can be different. Lion's economic scale is low due to the high fleet and high flight frequency, so overall it can set prices lower than competitors. When the busy period of the tariff is set as high as possible, on the contrary when the peak-off period is set low to compete with the substitute products or services of land and sea transportation modes.

5) Rivalry (Competition between existing competitors). The number after of airlines deregulation has increased from 5 to 73 companies). Of the amount is estimated only 15 companies that still can compete the rest have gone out of business. This amount is actually fulfilling the requirements under Flight Act No. 1 of 2009 as an airlines with only two or three group ic. State-owned Enteprice (SOEs) group Garuda (and Citilink) and Private-Owned Enteprice/POEs (group Lion, and Group Sriwijaya). Competition is a direct contest among competitors. As a newcomer to win Lion preferred the price/LCC competition strategy compared to the full service strategy, with multiple aims and objectives : (1) seize the incumbent airline market share (GIA, MNA, BOU etc) and (2) as a new player predator (entrance). The effect on the competitors as a whole the number of airlines becomes less, and lion win in competition.

These five industrial structure powers above determine Lion's profitability. But the evolution of the industry, the value of LCC's superiority on Lion airlines 
has declined. The decline is not only due to the declining consumer confidence as well as the increasing number of airlines that run the same LCC strategy. Initially the airline running LCC in Indonesia only Lion. Then the Garuda group with it Citilink, next Sriwijaya Air with Nam Air and followed by other airlines. Another big difficulty Lion since 2011 and 2013 has ordered 462 fleets. The planes had arrived and had to be flown. Lion saw that its growth in Indonesia would be limited and slow due to infra-structure problems (airport and flight navigation). Rapid growth can only be done outside Indonesia. Because Lion has long planned to build cooperation with foreign parties, but seems not to bring the results as expected (Ringkang Gumiwang, 2016). There are constraints that need to be manifested well and correctly (gerryonline.blogspot.co.id).

\section{Conclusion}

Based on the market structure analysis Lion has managed to dominate the airline business in Indonesia, with the largest market share since 2007 until now. Its success is because it can successfully cope with five competitive forces: (1) buyer, (2) suppliers, (3) replacements, (4) newcomers and (5) rivalry. All five create competitive competitiveness in the implementation of LCC's flight strategy. LCC can survive long lasting but not forever. The evolution of the LCC's value industry declined, pushing a heavy burden on Lion, as almost all airlines run the LCC, which means Lion has no strategy. Lion is now in big trouble. Urgent need another new strategy to maintain and even improve the company's performance.

\section{References}

Gerryonline.blogspot.co.id/2012/09/malindo-airways-lion-air-mengaum-dinegeri Jiran-html.

Haula, R (2008), Rekontruksi Konsepsi Supply-side Tax Policy, Bisnis \& Birokrasi, Jurnal Ilmu Administrasi dan Organisasi, Sept-Des 2008, Volume 15, Nomor 3, Universitas Indonesia Depok. 
Indra Setiawan, Dewi Nusaningrum dan Yosi Pahala. (2015). "Deregulasi Penerbangan dan Kinerja Perusahaan Penerbangan Niaga Berjadwal di Indonesia”. Jurnal Managemen Transportasi \& Logistik Volume 02 Nomor 01, Maret 2015 Jakarta: STMT Trisakti Jakarta.

Keputusan Menteri Perhubungan Nomor KM. 11 Tahun 2001 tentang Penyelenggaraan Angkutan Udara.

Kuntjoroadi, Wibowo, safitri, Nurul. 2009. "Analisis Strategi Bersaing dalam Persaingan Usaha Penerbangan Komersial, Bisnis \& Birokrasi”, dalam Jurnal Ilmu Administrasi dan Organisasi, Jan-april 2009, hllm.45-52. FISIP UI, ISSN 0854-3844.

Kokoh, R.A, (2015), Menebak Arah Low Cost Carrier, Kepala Divisi Konsultasi PPM Managemen (PPM Consulting), KRA@ppm-managemen. Ac.id.

Magretta, Joan. 2014. Understanding Michael Porter. The Essential Guide to Competition and Strategy. Panduan Paling Penting tentang Kompetisi dan Strategi (Diterjemahkan oleh Diana Kurnia Setialie). Diterbitkan oleh Penerbit ANDI.copyright@2014, Yogyakarta.

Michael E. Porter. 1980, Competitive Strategy, Alih Bahasa Dalam Bahasa Indonesia oleh : Ir. Agus Maulana, MSM, dengan judul : Strategi Bersaing, Tehnik Menganalisis Industri dan Pesaing, Institute Pendidikan dan Pengembangan Managemen, Penerbit Erlangga.

, 2008, "The Five Competitive Forces That Shape Strategy," Harvard Business Review, January 2008, 78-83. Hak Cipta@ 2008 oleh Harvard Business Publishing.

Mufti, Azhari. 2004. Implikasi Kebijakan Transportasi Udara Terhadap Industri Penerbangan di Indonesia. Jakarta: Fakultas Ekonomi Universitas Indonesia depok.

Osborne, David and Ted Gaebler, 1996. Reinventing government : How the entrepreneurial spirit is transforming the public sector. Diterjemahkan oleh Abdul Rosyid : Mewirausahakan Birokrasi, Penerbit Pustaka Binaman Presindo,.Jakarta

Peter F. Drucker 1995, Managing In a Time of Great Change (Management Di Tengah Perubahan Besar). Alih Bahasa: Agus Teguh Handoyo. Penerbit PT. Elex Media Komputindo.

Ringkang Gumiwang, 2016, Bisnis.com, Jakarta. Maskapai Berbiaya Murah Jalin Aliansi, Konsultan Ke Internasional Tak Significant.

Tiarto dan Saptono. 2014. "Berbagai Halangan Masuk Pada Bisnis Penerbangan Berjadwal di Indonesia" dalam Jurnal Ilmiah Aviasi Langit Biru Volume 9 Nomor 18, Oktober 2014 STPI Curug Tangerang.

Undang-undang Penerbangan Nomor 1 Tahun 2009.

Undang-undang Nomor 5 tahun 1999 tentang Larangan Praktek Monopoli dan Persaingan Usaha Tidak Sehat. 